\title{
Origins of Bosnian humour and its role during the siege of Sarajevo
}

\author{
David Orlov \\ "Turar" Center for Research in Humanities and Social Sciences, Kazakhstan \\ dorlov@nu.edu.kz
}

\begin{abstract}
This article presents an ethnographic study of Bosnian humour during the siege of Sarajevo. The siege of Sarajevo, which followed the collapse of Yugoslavia, lasted four years. Despite the atrocities and war crimes committed against the residents of Sarajevo during this period, they are known for the spirit they demonstrated, and humour was a crucial element of this spirit. On the basis of two-month fieldwork in Sarajevo, I demonstrate how Bosnians employed humour to comment on this traumatic event, made sense of it, and coped with the experience. Although humour under extreme conditions is mainly viewed as a coping mechanism, by exploring the origins of Bosnian humour and stereotypes about Bosnians, I demonstrate that a notable humorous response to the traumatic events of the 1990s was more than a coping mechanism or just a response to this particular war. As I argue, a humorous attitude toward life in Bosnia belongs to people's identity; it has developed historically as a response to the sufferings of a peripheral group in the region and, as a result, has become a cultural artifact belonging to Bosnians' ethnic consciousness. In their attempt to preserve a sense of normalcy and restore dignity during the siege, Sarajevans continued to engage in their traditional humour, as doing otherwise would mean they had lost control over who they were.
\end{abstract}

Keywords: ethnic humour, humour under extreme conditions, stereotypes, the siege of Sarajevo.

\section{Introduction}

A few years ago, I came upon the phenomenon of Bosnian humour for the first time. Specifically, I heard that people in Bosnia and Herzegovina tell jokes about the horrors they have lived through during the wars of the 1990s. After the breakup of Yugoslavia, Bosnia and Herzegovina experienced an ethnic conflict, four years of a siege on its capital, and the genocide of approximately 8,000 Bosnian Muslims in Srebrenica. While conducting preliminary research, one of the first jokes I found online was "How was Auschwitz better than Sarajevo?" and the answer was "At least there was gas". The joke may raise moral concerns among outsiders, but it was normal, and still is, for people in Bosnia and Herzegovina to engage in self-directed and self-deprecating humour. At the time, being unfamiliar with humour research, the type of humour surprised me. A layman, as I was, usually assumes that horror and humour constitute 
conflicting mental states (Carroll 1999). That surprise stemming from my ignorance of humour studies led me to this research.

In this study, I provide an ethnographic analysis of Bosnian humour. The primary emphasis is on siege humour. Sarajevo, the capital city of Bosnia and Herzegovina, was besieged from April 5, 1992, to January 29, 1996. Now, this incident is known as the longest siege of a capital city in the history of modern warfare. Besieged Sarajevo is famous not only for the daily horrors experienced by its citizens and the war crimes committed against them, but also for the spirit that helped the city survive. Humour constituted a significant part of that spirit. As Srdjan Vucetic (2004: 22), a scholar of Bosnian origin, summarised, "Sarajevo owes a large part of its fame to the fabled spirit of its besieged citizens, who have employed humour to defuse the tension". Although this statement is correct, assuming Sarajevan siege humour as only a coping mechanism is a simplistic view of the phenomenon.

What is true is that humour in non-humorous contexts may be considered a coping mechanism; the siege of Sarajevo is no exception. However, in the case of Bosnia and Herzegovina, humour should not be viewed as a mere response to this particular war, because humour as a coping mechanism has been used there for generations and has become a visible and distinctive element of Bosnian identity. By continuing to engage in self-directed humour during the war, Bosnians fought back by imitating the normal life that they had before the war, and humour was part of that life.

In this paper, I argue that one of humour's crucial functions was the restoration of the dignity of a minority group within the region. Classifying Bosnians as a minority might be perceived as paternalistic, and many Bosnians may disagree with this classification; therefore, clarification is required. The minority status here implies that Bosnians are historically a peripheral group and had disadvantages compared with other national groups, such as Serbs and Croats, for example, because Belgrade and Zagreb were the central cities. It is also derived from the participants' self-perception and their perception of what others thought of them. Some of the participants mentioned that Bosnia was similar to a child or orphan that other groups attempt to care for, or a smaller nation. This status has resulted in stereotypes that are accepted by Bosnians and are at the core of Bosnian humour. In the former Yugoslavia, Bosnians are considered, both by Bosnians themselves and others, as simple, open, and nice people with a great sense of humour. Humour is a daily attitude toward life among people in Bosnia and Herzegovina. It belongs to the ethnic consciousness because Bosnians believe that humour belongs to their identity; thus, it is not surprising that it persisted during the war and the siege of Sarajevo.

For this paper, I conducted fieldwork in Bosnia and Herzegovina, in July 2019 and then again in December 2019. At first, my goal was to interview the general public. Before arriving in the field, I was searching for events to attend in Sarajevo and for people to meet in order to collect data. During the period of my first fieldwork, the War Art Reporting and Memory (WARM) festival was scheduled to be held in Sarajevo. This annual arts and human rights festival attracts journalists, academics, and artists from around the world, many of whom were in Sarajevo during its siege. As my entry point to the Balkan region was Belgrade, where I applied for a Bosnian visa, I searched for festivalgoers who were based in Belgrade; Jelena Grujic was among them. Jelena was a Serbian journalist and human rights activist who covered the first months of the siege of Sarajevo for a newspaper she worked for at the time. Jelena knew a lot of people in Sarajevo, including the founders of the WARM festival and people actively engaged in the cultural life of Sarajevo during its siege. Her recommendations helped me meet them, and they further introduced me to more participants. During my two months in the field, I conducted 27 interviews. Most of the interviewees belonged to the wartime generation. In addition to the general public, I interviewed people who fought in a cultural war against the besieger and who produced humour on the radio and television and in the cinema and literature. 
The presence of humour in Bosnia during the war is not a unique phenomenon. Humour has long existed in non-humorous contexts. For instance, Holocaust humour has attracted wide academic interest (Ostrower 2015). Today, war-related jokes, such as the aforementioned joke about gas, may sound abnormal or immoral, especially if told by an outsider, but in Bosnia and Herzegovina during the war and during the siege of Sarajevo, such jokes were widespread. Humour does not only arise in the moments of happiness but also in situations that are miserable and depressing. Scholars in the field of humour studies collectively agree that humour under extreme conditions might be widespread and used as a tool to fight back against the aggressor, to cope, or to avoid seriousness (Chapman 1983; Chafe 2007; Kreševljaković 2015).

One of the interviews I conducted was with Remy Ourdan, a French journalist for Le Monde who was on the ground covering Sarajevo during the whole period of its siege. Ourdan also covered almost every major contemporary conflict worldwide, and he commented on Bosnian war humour:

I suspect there was always this sense of humour, but during the siege, because of that brutal switch to an extreme survival mode, and because you can die any minute, I think there was also an extreme sense of humour. People would still gather in cafes without coffee and tell jokes. I have been to many war zones, there is always this moment to get a little bit of air, a little bit of humour. But never like here, in Bosnia it was special.

The specificity that Ourdan noticed in the case of Bosnian war humour is related to the local culture and should be explained by examining its origins. The humour is neither simply a coping mechanism nor just a response to this particular war. It is linked to the identity of people living in this country. Why did humour have such a substantial role during the war, and generally, in the lives of Bosnians? Why do Bosnians think that humour belongs to their identity? Why do they assume that they have a good sense of humour? Why do they enjoy having the identity of the funniest people in the region? Why do they make fun of themselves rather than of others?

Bosnians believe that their humour is special and plays a crucial role in their daily lives. Almost every participant in the study expressed agreement about the importance of humour for the local community and Bosnians' special talent for telling jokes, making statements such as "our culture is rooted in irony and sarcasm", "we are funny and make jokes easily, we are quick in humour", "humour is a way of life, something that connects dots in our everyday life events", and "we were good at telling jokes forever". To be honest, some participants denied the idea that Bosnian humour is somehow special but still agreed that it plays a significant role in their culture.

\section{Are there limits to jokes and humour?}

Humour is ubiquitous and universal but can be culture specific as well: what is humorous in one society may be offensive or unacceptable in another (Critchley 2002). Returning to the joke "How Auschwitz was better than Sarajevo?": in most of the world, it would be unacceptable. Nevertheless, in Sarajevo, it was a famous joke, and even today, many residents who survived the siege still remember it. The joke is actually about necessity, not about Auschwitz. There was a shortage of gas, water, cigarettes, and hygiene products. People could not make coffee without gas, could not keep themselves clean because there was no water, and washing clothes in the Miljacka River was too dangerous because of the snipers around the city, although people still did it. The response of the besieged population was to make fun of themselves, as they did before the war. If you ask a Bosnian to inform you about their humour, one of the first things that would be mentioned is that it is very dark; as some of the interviewees mentioned, "whatever happens in the morning, by the night we have a joke about it. Especially if it is something really bad, 
something we shouldn't joke about" or "if we are talking about specifics of our way of humour it's a dark humour, like a tragic comedy". Jokes about necessity and poverty, if not universal, at least exist in numerous societies. In this case, this universal topic of humour was in a specific cultural context where dark humour is widespread.

Critchley (2002) views the comic world, or comical situations, as a place populated by people knowing the rules of the game and participating in it, for example, when someone throws you a ball, you do not keep it in your pocket but throw it back; the same is with humour. When Bosnians exchanged this and similar jokes, they were playing a game, the rules of which they knew. There was a tacit consensus on what constituted local humour and what jokes were allowed. As Critchley (2002: 4) states, the congruence between social structure and joke structure is essential for the humour to be considered humour.

In 2017, the Economist published the article "Bosnia's stand-ups jest about genocide" (M.C. 2017). Their journalist visited Sarajevo to collect material on the stand-up scene of the city and became interested in siege humour. One of the local stand-up comedians, Navid Balbulija, shared some war-related jokes, but regretted it when the article was published. The article starts with the joke about the widow who was asked to identify her husband's body: "The problem is that the mass grave that has been excavated only contained the men's lower halves. The woman is led from body bag to body bag and presented with the remains in each. 'That's not him. That's not him. That's not him', she says. 'And this guy's not even from Srebrenica!'”. The article became a matter of controversy in Bosnia because the author interpreted the joke improperly. I have interviewed Navid and have a full account of what he actually said and meant.

An actual joke, as Navid explained to me, goes this way, "Fata is asked to recognise Mujo. The problem is that there were only the men's lower halves. She goes 'he is not my husband, he is not, this one is not from our village"". Fata and Mujo are fictional characters in most Bosnian jokes, these names refer to the Muslim identity of the characters and to Bosnian Muslims in general. These two denote Fatima and Muhammed, traditional Muslim names used in jokes, and there are also Suljo and Haso, which denote Sulejman and Hassan. In the local jokes about these characters, usually, when Fata is involved, the joke is about infidelity. When it features Mujo and Suljo, the joke is about some funny, foolish act that one of them has committed. Srebrenica is assumed in the joke, but it cannot be mentioned. There have to be some limits, and Srebrenica is the line that cannot be crossed. Notably, that joke may still be perceived by many Bosnians as highly inappropriate and immoral. There can be no unified consensus in terms of humour appreciation. The joke, apart from the topic of infidelity, highlights the self-directed humour of Bosnians: they make fun of themselves rather than of others. This joke is a perfect example because it targets Bosnians, namely Fata's infidelity, rather than the individuals who have committed atrocities in Srebrenica. As Navid mentioned in the interview, it was a matter of economy in the Economist: the author pointed out what could attract the readers' attention. Although Navid attempted to explain to the journalist that Bosnians tell such jokes to cope with negative situations, that was lost in the article.

The discussed jokes about necessity and infidelity, if not universal, at least exist in many societies. Žižek claimed (2014: vii) that jokes have no authors: "[a] crucial feature of jokes is that they never seem to have an author, as if the question 'who is the author of this joke?' were an impossible one". The same type of jokes can be observed in various cultures, such as about fools or lazy or cheap people. I have heard the same joke about a Bosnian emigrant who was hired in a country abroad and told by an employer, "Oh, you are Bosnian, I know you are lazy", and the Bosnian replies, "No, those are Montenegrins, we are stupid". Every time I heard that joke it was personalised by the teller, as if he or she knew it from personal experience and it was about his or her friend, or even a famous Bosnian football manager who was hired in Japan. 


\section{Stereotypes, their origins, and self-directed humour}

Humour is a widely discussed topic in the former Yugoslavia, not just in Bosnia and Herzegovina. There are constant debates and comparisons - who is funny and who is not, or who is the most or the least funny in the region. The region comprises six former Yugoslav republics: Bosnia and Herzegovina, Croatia, Macedonia, Montenegro, Serbia, and Slovenia. Notably, when discussing Bosnian humour, I am referring to all groups residing in this multiethnic state: Bosniaks (Bosnian Muslims), Croats, and Serbs. All the residents of Bosnia are assumed to have a good sense of humour, including Croats. However, Croats from Croatia are considered the least funny in the region. For instance, a local university professor of psychology was the first to introduce me to this stereotype: 'I don't know if you know, the Croats don't have humour. There is Croatian comedy, but who watches that?". Similarly, a stand-up comedian from Mostar continued this thought: "The way they act... they need to vocalise it, they cannot act their feelings. In ex-Yugoslavia, Zagreb and Croatia are viewed as the least funny". The comedian concluded that, despite his awareness that these characteristics are stereotypes, it was often difficult for him to explain to the local public that a stand-up comedian coming from Zagreb to Mostar could be funny. Serbs from Bosnia and Serbia, by contrast, are famous for their good sense of humour. Similarly, Montenegrins are known for their good sense of humour, but Slovenes are in competition with Croats. Macedonians are excluded from this discourse, but the reasons for this phenomenon are beyond the scope of this research.

In general, the aforementioned scales of funniness and assumptions regarding who has or does not have a good sense of humour are rooted in local stereotypes. Allport (1958) claims that stereotypes may be either totally unsupported or derived from exaggerations. Indeed, the origins of stereotypes may be dubious or misrepresentative; but when they are in place, they play an important role in how the stereotyped individuals behave and perceive themselves and are perceived by others. In the former Yugoslavia, stereotypes were widespread, and everyone was aware of them. The most famous stereotypes are about Bosnians and Montenegrins: the former are perceived as stupid and the latter as lazy. There are many jokes about these two ethnic groups, for instance: "Why did the Montenegrin become so lazy? Because the Bosnian once said to him: "Let me explain..." (Vucetic 2004: 14). Both Slovenes and Croats are stereotyped as boring and trying too hard to be European. Additionally, Slovenes are stereotyped as stingy and Croats as overly religious. Serbs are viewed as militant, savage, or farmers, although the participants of this research have not expressed a general, widely accepted stereotype about Serbs. In the jokes, Serbs are mocked for trying too hard to be superior, such as "from Belgrade to Tokyo" or "Serbs were there before the amoebas". Although some of these stereotypes may be refuted by those to whom they are ascribed, Bosnians accept them well. Stereotypically, Bosnians are both funny and stupid. Pjer Žalica, a prominent Bosnian movie director and participant of this study, attempted to explain the connection between the two: "I suppose that we are the funny ones in the jokes and also we are the stupid ones. I think the notion that we are funny comes also from there".

In terms of targets, humour can be directed either at self or at others. This research focuses mostly on the former case because Bosnian humour is traditionally self-directed. Kreševljaković (2015) mentions this characteristic as a distinctive feature of Bosnian humour: "It is different because of its self-criticism, it does not ridicule others but instead, its main characters laugh at themselves". Vucetic (2004) claims that, in the former Yugoslavia, there was an unwritten common wisdom according to which Bosnians target themselves in their jokes. He further asks himself a question: "But why is the Bosnian dumber than others? Why do $I$ tell a joke in which my people turn out to be dumb?" (Vucetic 2004: 8). Almost every participant in this research asked himself or herself this question during our discussions. The most common answer was that it is a means of coping and rising above the situation. However, why is this specific 
self-humiliating strategy collectively employed? Üngör \& Verkerke (2015) argue that some groups, such as European Jews, for example, assign negative stereotypical qualities to themselves, and the case of Bosnian humour may represent a similar phenomenon. What remains unclear is if those stereotypes were initially ascribed by the Jews and Bosnians to themselves or assigned by outsiders and later accepted and internalised.

Drawing on philosophy and modern psychology, Rappoport (2005) argues that ethnic humour is used because of the need to cope with the risky nature of interpersonal relations. $\mathrm{He}$ derives this conclusion from the assumption that anyone who is seemingly different may be perceived as a potential threat. Alternatively, Davies (1998) suggests that fear of interpersonal relations can be better expressed among similar groups; thus, the need for differentiation among them emerges. The case examined in this study confirms the latter opinion; in the former Yugoslavia, the nation groups had a lot more commonalities than differences. Similarly, French jokes about stupidity refer to Belgians and not, for example, to Austrians, because the former are more similar to them than the latter, as well geographically closer, which to a certain extent implies similarity as well. In England, people ascribe stupidity to the Scots, not to their traditional enemy, the French. The need for self-identification through stereotypes arises in societies where similar groups live together, not vice versa.

The stereotype of being a stupid group is one of the most widespread in the world. Davies (1998) concludes that, in almost every society worldwide, there is a group targeted as stupid. Notably, tracing the origin of these opinions is difficult. For example, in today's Egypt, Nubians are targeted as fools, and the origin of this stereotype is from a script over one thousand years old (Davies 1998: 11). However, the origin cannot be confirmed; the script was probably recapitulating an existing stereotype. A notable finding on the subject is that most of the presumably stupid groups have adopted this stereotype through humour. Davies points out that Scots, Jews, Newfoundlanders, and Australians - among others - are famous for self-ridicule, specifically, for jokes about their presumed foolishness.

Davies (1998) also argues that certain characteristics are ascribed to groups living at the margins of a particular society - the peripheral groups. Numerous groups may be included in this category, such as immigrants, the poor, and rural residents. Ethnic jokes usually imply opposites, for example, rich and poor, city and rural residents, or original residents and arriving immigrants, and those characterised by the former make fun of those who belong to the latter. In most cases, the latter group is considered to be suspicious and poorer and to have backward infrastructure, lower access to schools, and strange cuisine. These backward characteristics serve as the ground for jokes about stupidity. Bosnia and Herzegovina within the former Yugoslavia region represents the case of a society at the margins or the edge. Other nation groups, such as Croats, Serbs, or Slovenes, have a history of statehood; Montenegrins are proud of their opposition to the Ottoman conquests; and Macedonians similarly derive some degree of pride in history. Bosnia and Herzegovina, by contrast, has always been governed and has no history of statehood. Participants in this study often characterised Bosnia as an orphan or a child whom other groups attempt to care for. Infrastructural and geographic backwardness was also expressed by the informants, for example: "Resources have been centred in Belgrade and Zagreb, as the major cities of the country, Slovenia has always been a more European among us, we were far away from the biggest cities or the sea".

In almost every case, the group that is stereotyped as stupid represents the minority within the larger society. But, why minority groups accept these stereotypes and engage in self-ridicule reinforcing those stereotypes remain unclear. Studies of intergroup humour in societies having a majority-minority division have shown that the minority groups produce more jokes and humour than the majority (Nevo 1984). Additionally, the jokes are mostly self-directed, as well as self-deprecating. Some have argued that ethnic humour may be pleasurable, even for those at whom it is directed, because it does not ridicule the target as an ethnic group, but only its 
distinctive features. Berger (1993) suggests an Irishmen as an example. Berger argues that they are ridiculed for their culture of drinking, not because they are Irish per se. Such a perspective looks like an excuse for ethnic humour; furthermore, it does not explain the pleasure that the targeted group supposedly experiences in self-ridicule. On the contrary, especially for groups ridiculed for presumed stupidity, such an explanation is humiliating. Following Berger's logic, "stupid Bosnian" is not a joke about Bosnians per se but about them being stupid, what is not true. Such an approach legitimises the stereotypes. That most of the minority groups ridiculed for presumed stupidity have accepted this negative stereotype implies that they find some usefulness and pleasure in it.

The pleasure principle is at the core of Freud's understanding of humour: "Humour is not resigned; it is rebellious. It signifies not only the triumph of the ego but also of the pleasure principle, which is able here to assert itself against the unkindness of the real circumstances" (Freud 1927: 19). One of the participants of this research stated:

Everybody else was making fun of Bosnians, and we said ok if you make fun of us, let us show how it is done. You can fight them but it is not useful. Basically, we embraced those stereotypes about Bosnians that we are sometimes stupid, really simple people, who want to eat, drink, and have sex, as if we don't have any other desires. In that way, everybody else cannot make worse jokes about you than you can do about yourself.

The frequency of humour, especially self-directed humour, observed among minority groups lies not simply in the status of minority per se but in their suffering, difficulties, oppression, and stigmatisation. Using humour, they fight back and restore their dignity. The pleasure principle lies within this struggle, when they rise above the situation. Rappoport (2005) uses the metaphor "sword and shield" to explain the different goals of ethnic humour for majority and minority groups. Both groups use it for different reasons, depending on their goals. The majority strive to preserve the status quo because they are in a privileged position. Conversely, the minority are unsatisfied with the existing status hierarchy and are attempting to change it. Individuals prefer not to be ridiculed, and when the oppressor, in this case a dominant group in society, targets members of the minority group in their jokes, the latter may feel humiliated and experience a loss of dignity. Self-directed humour is a tool to restore this lost dignity.

Unable to challenge the status hierarchy in an overt manner, minority groups must employ unconventional techniques, and humour is among them. Almost every participant in this study linked the prevalence of humour in Bosnia to a long-lasting tradition of oppression. One of the interviewees said that Bosnians have a good sense of humour because they have suffered a lot throughout history. Others mentioned that the word Sarajevo implies heaviness, meaning that the city has a history of wars, invasions and suffering. According to the participants of this research, Bosnia and Sarajevo have always experienced the most damage from wars throughout history. Humour has become a natural coping mechanism that they use to cope with daily hardships, and, over time, an inseparable part of their culture. Other groups, such as Serbs, could say the same; but they were in a relatively dominant position historically, having the strongest army in the region, military successes, and power and resources (mainly concentrated in Belgrade).

Rappoport (2005) draws the same conclusions about Jews and African Americans as I do in this research about Bosnians: all three groups developed a good sense of humour because they have suffered the most and were ridiculed and stereotyped. Bosnians accepted the stereotype and internalised it through humour to fight back and to restore their dignity. By accepting the assigned stereotypes, Bosnians have achieved a transformation from laughing at to laughing with. In his study of laughter in interaction, although not mentioning the case of 
Bosnians specifically, Glenn (2003: 119-120) talks about the positive effects of such transformation:

[a] willingness to go along with, or even initiate, laughter at oneself provides potential payoffs in realigning towards affiliation. Once laughing at either is underway or relevant, willingness to laugh at self provides a resource for converting the environment to laughing with.

Glenn argues that this transformation allows changes in the social structure, and provides an extract from the autobiography of Dick Gregory, a comedian, to make the point:

I got picked on a lot around the neighbourhood. I'd just get mad and run home and cry when the kids started. And then, I don't know just when, I started to figure it out. They were going to laugh anyway, but if I made the jokes they'd laugh with me instead of at me. I'd get the kids off my back, on my side. Before they could get going, I'd knock it out first, fast, knock out those jokes so they wouldn't have time to set and climb all over me. And they started to come over and listen to me, they'd see me coming and crowd around me on the corner

(Gregory 1964: 54-55, cited in Glenn 2003: 120).

Gregory's experience is similar to what the participants in this study alluded to in the interviews, for example: "If you make fun of us, let us show how it is done". By accepting the stereotype of funny fools, Bosnians have achieved the transformation of social structure that Glenn mentions. While accepting and internalising negative stereotypes, Bosnians have created a positive self-image. The archetypical fool is actually perceived as a smart figure of fun and as Daniels \& Daniels (1964) argue, has a "licensed freedom". People admire the fool's ability to get away with what he says in jokes and the readiness to be the target of the laughter (Daniels \& Daniels 1964: 219).

Rappoport (2005) argues that stereotypes are not primarily about prejudices but about a sense of pride that minorities see in the stereotypes per se. This sense of pride is rooted in the ability of minority groups to come out on top in ethnic jokes, which is also related to the principle of pleasure. In the jokes that they make, Bosnians come out on top because it is the Bosnians who tell these jokes.

A Montenegrin, a Serb and a Bosnian come to the railway station. Once they arrive, they realise that the train is leaving. They start running: the Montenegrin gives up immediately, the Serb shortly afterwards, only the Bosnian manages to hop on the train and leave. The Montenegrin and the Serb return looking somewhat discontented. A person who observed it all asks them: "How is it that the Bosnian got on, and you didn't?" - "Oh, that guy?! The fool was only supposed to take us to the station".

(Vucetic 2004: 8)

While portraying themselves as stupid in jokes, they actually consider themselves as smart and witty. The wit is not necessarily in the events of the plot but in the means of telling the story. In other words, the joke teller comes out on top, even if one of his/her co-nationals is made to look buffoonish in the plot of the joke. The triumph is derived from the context - that the teller is Bosnian means that the joke teller is sufficiently witty to score a laugh and sufficiently selfconscious to recognise how outsiders view him.

Norrick (1993: 47) argues that self-deprecating humour serves the function of presenting oneself in a positive fashion:

Funny personal anecdotes end up presenting a positive self-image rather than a negative one. They convey a so-called sense of humour, which counts as a virtue in our society. They present a self with an ability to laugh at problems and overcome them - again an admirable character trait. 
Bosnians not only accepted the stereotype of funny fools, but they made a brand out of it and are proud of it. Throughout the interviews, the participants mentioned that Bosnian humour is an example of true humour. Having such humour is perceived as a noble character trait. For example, one of the participants of this research stated:

We think that it is very noble if you can tell a joke about yourself, the quality of humour lies there. If you make a joke about others, in which you are excellent and the other is stupid, this is the most miserable level of humour. We tell jokes about ourselves and relief, release our spirit.

Critchley (2002) argues that humour directed at yourself is the highest form of humour. Quoting Samuel Beckett, he calls laughing at yourself "risus purus." Despite laughing at your problems, such humour does not make you unhappy; on the contrary, it elevates and liberates you. Such humour is pleasurable.

This ability to present the self as a figure of fun is valued not just by the joke tellers but by others as well. Senad Pecanin, a participant in this research, stated that Bosnians are welcomed and appreciated in the region because of their openness and ability to tell jokes about themselves. There is a saying in the Serbo-Croatian language, "*ebo zemlju koja Bosne nema," which can be translated as " $\mathrm{f} * \& \#$ the land that has no Bosnians". This saying implies that it is nice to be around Bosnians because they have a great sense of humour, in same way it was nice for the children to be around Dick Gregory in the aforementioned example. The saying can be uttered by the members of any other group in the region who appreciate Bosnians' sense of humour and their openness. Bosnians have internalised the stereotype to an extent that it is now unclear to the general public in the region how it originated and who first said that Bosnians were stupid. The negative stereotype has been transformed into a positive identity characteristic.

\section{Siege humour}

Thus far, the origins of self-directed humour among minority groups have been explained by the history of oppression and suffering. However, what was not explained was who was the oppressor while Bosnians were being oppressed. This seemingly over-simplistic denomination may seem dubious without grounding it in history-related literature, but it was not taken out of nowhere. The participants in this research did not openly name a historical oppressor but drew a link between their humour and historical suffering, implying that there was always someone who governed or invaded Bosnia.

We are a country that has been suffering since its existence. It is not just this war, but every war. We are really a culture and a place that carries this spirit and this memory. It is our reality and who we are. This is I think one of the reasons why we turned out the way we are, we have a culture in which we use humour to ease the pain that is inevitably there.

Bosnia was always at the crossroads of different empires, conquerors and different people were coming to Bosnia. Probably it was the only way to survive, to keep your spirit up and to preserve it, to survive all these invaders. Our country was always invaded.

If you read the history of the Balkans or of the ex-Yugoslav republics, Bosnia was always hit the hardest.

The goal of this study is not to conduct a literature review to assess the extent to which such claims are historically supported. What is important is that the ideas expressed in these statements are widely shared and relate to the topic under study. 
When jokes are told, they usually focus on the present, not the past. Although there may be some, I have not heard jokes about Austro-Hungarians or Ottomans, who invaded the current territory of Bosnia and Herzegovina; those would not be of current interest in a daily conversation. This reason probably explains why the participants did not name a particular historical oppressor. In the 1990s, the situation was different. Sarajevo was besieged for 1,425 days. Sarajevans knew who the snipers hiding in the mountains around the city were; who was cutting the electricity, gas, and water; and who was gradually and purposefully destroying the city and killing its civilians. In the presence of an obvious oppressor, did the target of the jokes shift from the self to the other?

One of the common implicit assumptions in the literature on humour in Bosnia during the war is that it has changed and became more aggressive, and that the target of the jokes became the other instead of the self, which is generally an uncommon practice in Bosnian humour culture. Üngör \& Verkerke (2015) highlight jokes directed at Serb nationalist leaders responsible for the war and atrocities, such as Slobodan Milošević and Radovan Karadžić. The authors are not wrong; such jokes indeed existed. For example, a joke comparing Serb President Slobodan Milošević to Geppetto (Slobetto) and his protégé in the Bosnian Republic of Srpska, Radovan Karadžić, to Pinocchio (Radovanocchio) appeared in an article written by a Bosnian journalist in The New York Times (Sudetić 1993). Other targets of such jokes were Croats, with whom Bosnians also had a war in some parts of the country, such as in the Herzegovinian region. Jokes about passive United Nations peacekeepers were also observed.

A similar case in the studies of humour under extreme conditions is the case of the Holocaust. Jews are as famous as Bosnians for self-directed humour, and started targeting Nazis in their jokes. However, it is questionable if such humour became more widespread than selfdirected humour. Ostrower (2015) demonstrates that in concentration camps, the most frequent type of joke was self-directed in nature. Self-directed humour, in the view of Holocaust survivors, was a tool against the Nazis' attempts to dehumanise them, to feel that they were still human beings. Similarly, in Bosnia, although there are no quantitative studies of siege-related humour, it is considered that targeting the enemy was not something usual or normal, and Bosnians themselves remained the targets of local jokes. Jokes about enemies existed but did not represent the norm. By not ridiculing their oppressors, they were different from them, with higher morale and dignity. The traditional self-directed humour persisted.

Bosnia and Herzegovina was considered the least nationalistic state in the former Yugoslavia, and Sarajevo was an unofficial capital of multiculturalism. One of the participants in this study claimed that one of the worst identity categories in a pre-war Sarajevo was being a nationalist. The siege of Sarajevo became a test of its multiculturalism, and Sarajevans are proud of their success in preserving that status quo despite the ethnic war. Remy Ourdan, a participant in this study and a journalist who covered the Yugoslav Wars for Le Monde, stated that in the region in general, Sarajevo was one of the two cities (another was Tuzla) whose residents collectively demonstrated anti-nationalist sentiment throughout the war. Humour was part of it. The type of humour Bosnians continued to practice demonstrates their opposition to new circumstances they have faced - they passed the test. Nationalistic jokes existed, but did not constitute a common humorous attitude:

Mujo hearing the news that Croats had demolished a mosque in Central Bosnia, responds: "It doesn't matter, we'll demolish their mosque in Zagreb".

(Kreševljaković 2015)

Croats in this joke are portrayed as the enemy, but the actual target is the Bosnian who narrates the joke; it represents traditional Bosnian humour directed at an individual's own stupidity. Mujo, a fictional character representing Bosnian Muslims, has insufficient critical thinking skills 
and is attempting to express that they wish to do to the same to the enemy that has been done to them, to demolish their mosque in Zagreb, a place of worship for Muslims. Although Mujo is a fictional character, the joke teller, similarly, expresses a feeling of invulnerability by telling this joke while living under the conditions of a constant threat to life in a besieged Sarajevo.

Although the jokes mainly continued to be non-aggressive toward the others, implicit aggression toward the self can be observed. A recurrent concept in the interviews was naivety. From the interviews, it was clear that in Bosnia, almost no one had believed that there could be a war. One of the interviewed participants, for example, stated that he did not think the war was possible even one hour before it started. The war was unbelievable until the time it actually started, and then it became obvious it was unavoidable. The participants described themselves as naïve because they could not imagine the war while probably knowing deep inside that it would happen.

The comedy group Top Lista Nadrealista (TLN), members of which were Sarajevans of different ethnic and religious backgrounds, became famous for their sketches about the life of ordinary people in Yugoslavia, both in Bosnia and in the region. Some of their most famous prewar sketches that were considered absurd at the time predicted the war. In one of them, the Berlin wall is still in place, Sarajevo is divided by the wall as well, and the parties on the sides are at war until only one person is left alive. In the interviews for this research, the leading members of the group Zenit and Elvis commented on their prophetic abilities:

Definitely we did not do that on purpose, it was spontaneous. The process of making a joke is to find some ideas which are unbelievable, completely unimaginable. And what you find in that way is funny. Separating Sarajevo, war in Bosnia and in Yugoslavia was unimaginable and it was funny. But then it became a reality.

When the war became a reality, people in Bosnia realised they were too naïve and, as a consequence, were unprepared for it. Fighters on the front lines were badly equipped; necessary resources were not in place on the day the war started. Although in the pre-war jokes, Bosnians played with their presumed stupidity to demonstrate actual smartness, during the war, some jokes aggressively pointed out Bosnians' naivety and foolishness because it was obvious that there had to be war. The realisation of their own naivety explains the increased aggression in some of the jokes toward the self, and the humour in this case was used as a tool for self-critique. However, aggression does not exclude the positive aspects of humour, as Norrick (1994: 423) argues: "Even if there is aggression in the message, there is solidarity in the humorous metamessage". When all members of a group experience the hardships, related humour refers to the common suffering and softens it by indicating that everyone else is going through it; additionally, everybody can laugh at the surrounding abnormality by relating to it (Archakis \& Tsakona 2005).

In talks about the siege period in Sarajevo, as well as in the literature on this period, one of the most frequent words mentioned is spirit. Survivors of the siege and war talk not merely about the atrocities they experienced, but also proudly describe how they creatively coped with them. Vucetic (2004) claims that the siege of Sarajevo did not gain its fame just because it was the longest siege of a capital city in the modern history, or because it was the first war in Europe after the Second World War, but also because of the spirit the besieged citizens demonstrated; humour contributed a lot to the spirit of Sarajevo. Culture became a tool to fight the oppressor and cope with the situation, and humour constituted a significant part of the cultural war against the besieger.

Although Sarajevans were lacking the means to fight the besieger directly, they were active in their cultural lives and thus, took the position of artists instead of victims (Hadžiosmanović 2014). It is the same position of invulnerability observed in self-directed humour: a refusal to accept a threatening reality. Almost every participant in this study has participated in that 
cultural war, which was a means to disempower the oppressor, to take control of their own lives despite the attempts of the besiegers to dehumanise them, and to make the besiegers' lives intolerable (Hadžiosmanović 2014: 24-28). By engaging in the city's cultural life, Sarajevans have demonstrated that the city still belonged to them. Writers continued to write, directors shot movies and documentaries, artists drew posters and posted them around the city, a beauty contest, "the Besieged Miss Sarajevo," was held, and the Sarajevo Film Festival was initiated. TLN continued making humorous sketches at the frontlines during the bombings, and under the sniper's shootings, they broadcasted their shows on the radio. One of the shows started with "good evening all three of you out there who still have batteries" (Sudetić 1993).

Boro Kontić, a participant in this research, TLN's producer and one of the active participants of Sarajevan cultural life during its siege, concluded that through humour, they were claiming their right to freedom on a daily basis. Humour was not only a coping mechanism but also a means to continue a normal way of life; claiming the right to be free was about living the way they lived before the war. War changes the lives of people accustomed to normal conditions. As Maček (2009) suggests, in wars, the old world is destroyed with its assumed norms, and the new wartime norms emerge. Humour may be used as a tool to manage the implied incongruity between the two (Maček 2009: 51-54). When there are new, seemingly abnormal norms, victims of extreme conditions feel a need to be "normal people," and this need belongs to their moral framework. Preservation of normalcy is a common response under extreme conditions (Maček 2009: 5-10). The participants of this research claimed that to be normal meant to be ethical, urban, cultural, Western, and educated:

When my friends-journalists who were going out and coming back would ask what I want them to bring me, assuming I would ask for something like food. Instead, I would ask for books, magazines, and perfume. These three items were more important. So, it is not to escape, but to pretend to have a normal life, type of imitation of normal life.

In this kind of situations, in exaggerated reality, you accept it. Expecting to be killed any minute, and then you try to live a normal life, kind of copy of life. That's what people do, I mean, otherwise you go crazy. You try to behave normally, telling jokes, making reality checks on the situation around.

To continue living a normal life implied rejecting new norms. Nevertheless, in some cases, living by the old rules implied a deadly threat. Because Sarajevo was surrounded by snipers, movement around the city changed - "to run or not to run" became an existential question. As one of the interviewees mentioned, Bosnians are known for a slow way of life: "It is just our way of life, it is slow. We are a lot slower than other people around the world". However, in the context of the fear of being shot by snipers, people lost their freedom to walk. Some people even refused to run, but many of them were shot by the snipers. Finally, running became the most common means of moving around the city. But it also assumed that they had lost control over their bodies, which diminished their dignity. A Bosnian writer, Ozren Kebo, a survivor of the siege, writes about running in the besieged city in his book Sarajevo: A Beginner's Guide:

I ran with water canisters in my hands. Everyone laughed at me. When you run with canisters, you tremble, your arms are not bent, but rather stretched out, your movements are distorted. And it looks so silly. However, the artistic impression is not that important, it's important to stay alive.

(Kebo 2016: 98) 
The dignity people lost due to the inability to walk normally was restored through humour. There are numerous jokes about running across the "sniper alleys". Another example is a humorous video (Ourdan 2016). An old-looking man wearing a hat, a cloak, and holding a case hears sniper shots. He slowly takes off the clothes, stands in track and field position, then starts sprinting. In the end, he victoriously jumps with his hands spread wide, and it turns out that he is wearing a Nike T-shirt. The video pauses and the Nike logo appears on the screen. Similarly, TLN members told me a story about a sketch they made during the war:

In one sketch during the war we suggested a new Olympic sport, running across the sniper alleys with the canisters full of water, because water was important during the war. So, we found a real sniper crossroad and made this sketch. People did not see the cameras, and they did not know what was going on, they thought it was a real fight. One of the actors fell down and pretended he was dying, and a taxi driver came to him and wanted to pick him up and to take him to the hospital. Our craziness in the sketches, in our ideas, was mixed with the craziness of the reality. We did not do it in safe areas, it was directly on the front lines.

To my question of why they would risk their lives to make such sketches, TLN members Zenit and Elvis replied that they could not stop; they had to continue because it was their job, both during the pre-war times and during the siege. They saw a need to provide their audience with humour, in order to help them cope with the catastrophe. Humour was as essential for people as water. It was a way to cope psychologically and to protest against the norms imposed on them by the besieger. Although Bosnians had to accept running as a new wartime norm, they also found a means to diminish the humiliation implied in the loss of control over their bodies through humour. Such humour could be perceived as abnormal, but, as the participants of the study mentioned, "if war and siege is your everyday life, then it is normal to tell jokes about death" or, "war is not a funny story, but when it becomes your life and you are under shelling every day, then you can tell jokes".

\section{Humour and Bosnian identity}

I remember, once, I and my future wife, have witnessed a manslaughter. We were walking home. There was a guy walking in front of us, around fifteen steps ahead. He crossed the street, we crossed, he passed the park, then we did, and then his head exploded like a watermelon. Sniper shot him. Just meters in front of us. And it was not funny, but just in ten minutes or maybe thirty, when we came home and talked about it, somebody said "luckily you were not jogging, because you would jog in front of him and would be shot instead". So, you start telling the jokes, not diminishing, not making it less important, but assuming it as something not sacred (personal memory shared by the participant of the research).

Humour, Bosnians believe, is part of their identity, and they continue engaging in it even under the most difficult conditions. Just as Bosnians continued going to the cinema, theatres, and concerts, they continue engaging in their traditional humour because it is an important element of their identity. Jokes, and humour in general, are oral traditions that provide information on a particular society. One of the group members in the aforementioned story joked: "luckily you were not jogging", which indicates that telling such jokes was considered normal in the framework of that situation; otherwise, it would have resulted in a sense of discomfort among the others who heard it. The research participant who shared the story admitted that it was normal to tell such a joke, and that the act of telling it and accepting it as normal by replying to it with laughter provides a sense of membership. In Critchley's (2002) words, there was a tacit agreement among the participants regarding what could be told in jokes. Having a common sense of humour provides a sense of thereness: "it returns to locality, to a specific circumscribed 
ethnos" (Critchley 2002: 68). By telling that joke, a joke teller has demonstrated his attitude toward the situation, and by going along with it, everyone else has demonstrated that they share it; the attitude of invulnerability was demonstrated in the concluding part of the story: "You start telling the jokes, not diminishing, not making it less important, but assuming it as something not sacred".

Additionally, not being able to engage in such humour could be a reason for exclusion from the group. Maček (2009) argues that in Bosnia, to be accepted into a group, especially during wartime, you had to demonstrate the capacity to laugh at yourself. It was a precondition for the spirit of solidarity among the group members sharing an experience. The highest form of social recognition in Sarajevo was to be a part of raja. Savija-Valha (2016) defines it as the mentality of a person, a code of conduct within a cultural milieu that requires individuals to respect these codes. Raja is a sort of imagined community, its members are normal people, and humour is a significant element of this normalcy. Being normal implies that you should not take yourself seriously but always approach yourself with irony. One of the participants of this research stated: "I think that when you grow up in a culture that is so strangely rooted in irony and sarcasm the first thing you have to learn is not to take yourself too seriously". In Sarajevo, everyone should be ready to be an object of irony for other members of the community. If you take yourself too seriously, you will be shown your place, because in raja, no one can rise above others, whether you occupy a high position in society or not. Savija-Valha highlights that it is not important to be a celebrity or rich, but it is important to be normal and treat others as normal people. For example: "Doctors and dustmen drink coffee together in Sarajevo" (Savija-Valha 2016: 171).

For my part, this sense of equality was one of the first things that I noticed in Bosnia and Herzegovina. Some of the participants in this study were local celebrities, such as members of TLN, singers, producers, or directors. When we went out together to bars or cafés, no one ever approached us asking to take a photo with them. Once, we went to a night club with Elvis J. Kurtović and his friends. As many people told me, Elvis is a legend in Sarajevo because of his membership in TLN and his rock-band Elvis J. Kurtović \& His Meteors. If you spend a few hours in any café in Sarajevo, you may hear at least one of his songs. Despite this, during that evening, no one paid any attention to him. At some point, the band performing the music invited him to sing one song. The whole club sang along and when he finished, at least for one minute, everybody was yelling his name, which is also in the lyrics of the song he performed: "Elvis Elvis Elvis J. Elvis Elvis Kurtović." Then, he returned to our table and was not disturbed by anyone until he left.

In Bosnia and Herzegovina, telling jokes is a part of being normal and raja. Not being involved in joking, by contrast, excludes you from raja. Raja is witty and implies competition"a battle for being cleverer"-you need to demonstrate that you can tell jokes about yourself and others and that you can take them (Savija-Valha 2016: 167). As one of the participants of the research stated, it is a process of initiation. While the jokes are often mean, you have to take them in order to be a group member. Despite being mean, the hostility in the jokes implies friendliness. One of the participants attempted to explain how people would talk to each other:

When you want to say something really simple like you were late to class, you would say ' $\mathrm{f}$ * $\& \#$ it, I was late to this $\mathrm{f}^{*} \& \#$ ing class'. Or if you talk to someone on the phone you could tell 'where are you, $f^{*} \& \#$ your mother'. When you translate it, you cannot believe it, and that is why I think we are a little primitive. Because we are accepting it like the folklore, as a way of communication.

It is important that the participant mentioned that talking this way is taken as folklore; it is rooted in the type of humour that is characteristic of raja-make fun of others and be ready to become an object of humour as well, regardless of the position in society you occupy. As an outsider, when people start ridiculing you, that means that they accept you-you have become raja. 


\section{Conclusion}

Hearing the seemingly abnormal Bosnian wartime jokes for the first time (for example, "How was Auschwitz better than Sarajevo?") may raise moral concerns among people unfamiliar with humour research or local culture. Victor Frankl, a Holocaust survivor, noted that "An abnormal reaction to an abnormal situation is normal behaviour" (Frankl 1992: 32). Similarly, abnormal humour is a normal reaction to an abnormal condition. Humour does not only arise out of positive emotions; it may also be widespread during the times we feel unhappy, depressed, or even threatened. In this paper, I demonstrated how Bosnians employed humour to comment on the traumatic events following the breakup of Yugoslavia, to made sense of them, and to cope with the experience. However, the phenomenon of Bosnian wartime humour should not be regarded as simply a coping mechanism or a response to this particular war or the siege of Sarajevo. For Bosnians, humour belongs to their identity, culture and folklore. It is a constitutive element of ethnic consciousness and raja. A humorous attitude toward the extreme conditions of the 1990s was a very normal and expected response in the context of this culture. Such an attitude stems from the Bosnian history of oppression and suffering that shaped local humour culture. In their attempt to preserve a sense of normalcy and restore dignity during the siege, Sarajevans continued to engage in their traditional humour, as doing otherwise would mean they had lost control over who they were.

\section{References}

Allport, G.W. (1958). The Nature of Prejudice. Boston: Addison-Wesley.

Archakis, A. \& Tsakona, V. (2005). 'Analysing conversational data in GTVH terms: A new approach to the issue of identity construction via humour'. Humor: International Journal of Humor Research 18 (1), pp. 41-68.

Berger, A. A. (1993). An Anatomy of Humour. New Brunswick: Transaction Publishers.

Carroll, N. (1999). 'Horror and humour'. The Journal of Aesthetics and Art Criticism 57 (2), pp. 145-160.

Chafe, W. (2007). The Importance of Not Being Earnest. Philadelphia: John Benjamins Publishing Company.

Chapman, A.J. (1983). 'Humour and laughter in social interaction and some', in McGhee, P. E. \& Goldstein, J. H. (eds.), Handbook of Humour Research, New-York: Springer-Verlag, pp. 135-158.

Critchley, S. (2002). On Humour. London: Routledge.

Daniels, A. K. and Daniels, R. R. (1964). 'The social functions of the career fool'. Psychiatry 27 (3), pp. 219-229.

Davies, C. (1998). Jokes and Their Relation to Society. New York: Mouton de Gruyter.

Frankl, V. E. (2006). Man's Search for Meaning: An Introduction to Logotherapy. $4^{\text {th }}$ edition. Boston: Beacon Press.

Freud, S. (1927). 'Der humour.' Passage 34, pp. 18-21.

Glenn, P. (2003). Laughter in Interaction. Cambridge: Cambridge University Press.

Gregory, D. (1964). Nigger: An Autobiography. New York: Dutton.

Hadžiosmanović, J. (2014). 'How is culture used as a tool for discussion of conflict and consensus: A case of Sarajevo'. Journal of Transdisciplinary Studies 7 (1), pp. 22-46.

Kebo, O. (2016). Sarajevo. A Beginner's Guide. Amira Sadiković (tr.), Sarajevo: Šahinpašić.

Kreševljaković, N. (2015). 'Humour under siege: Mujo, don't jump around, you'll get hungry'.

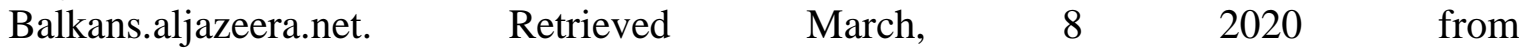


http://balkans.aljazeera.net/vijesti/humour-under-siege-mujo-dont-jump-around-youll-gethungry.

Maček, I. (2009). Sarajevo under Siege: Anthropology in Wartime. Philadelphia: University of Pennsylvania Press.

M.C. (2017). 'Bosnia's stand-ups jest about genocide'. Economist.com. Retrieved February, 15 2020 from https://www.economist.com/prospero/2017/10/17/bosnias-stand-ups-jestabout-genocide.

Morreall, J. (2009). Comic Relief: A Comprehensive Philosophy of Humour. New Jersey: WileyBlackwell.

Nevo, O. (1984). 'Appreciation and production of humour as an expression of aggression: A study of Jews and Arabs in Israel'. Journal of Cross-Cultural Psychology 15 (1), pp. 18198.

Norrick, R. N. (1993). Conversational Joking. Humour in Everyday Talk. Bloomington: Indiana University Press.

Norrick, R. N. (1994). 'Involvement and joking in conversation'. Journal of Pragmatics 22 (3/4), pp. 409-430.

Ostrower, C. (2015). 'Humour as defence mechanism during the Holocaust'. A Journal of Bible and Theology 69 (2), pp. 183-195.

Rappoport, L. (2005). Punchlines: The Case for Racial, Ethnic, and Gender Humour. Westport: Praeger Publishers.

Savija-Valha, N. (2016). 'Raja: The ironic subject of everyday life in Sarajevo', in Jansen, S., Brkovic, C. \& Celebisic, V. (eds.), Negotiating Social Relations in Bosnia and Herzegovina: Semiperipheral Entanglements, New York: Routledge, pp. 163-178.

Sudetić, C. (1993). 'This can't be Bosnia, there is too much laughter'. Nytimes.com. Retrieved February, 122020 from https://www.nytimes.com/1993/07/06/world/sarajevo-journal-thiscan-t-be-bosnia-there-s-too-much-laughing.html.

The Siege (2016). Directed by Remy Ourdan and Patrick Chauvel. Blanche Guichou, Agat Films $\&$ Cie.

Üngör, U. \& Verkerke, V. (2015). 'Funny as hell: The functions of humour during and after genocide'. The European Journal of Humour Research 3 (2/3), pp. 80-101.

Vucetic, S. (2004). 'Identity is a joking matter: Intergroup humour in Bosnia'. Space of Identity 4 (1), pp. 7-34.

Žižek, S. (2014). Žižek's Jokes. Cambridge: The MIT Press. 